\title{
THE GEOPOLITICAL CONTEXT OF THE CRISIS IN VENEZUELA
}

\author{
Dr. Ethar Anwar Muhammed \\ Department of Geography /Collage of Education, Iben Rushed/ Baghdad University \\ Baghdad. Iraq
}

DOI: $10.37648 / \mathrm{ijrssh} . v 10 \mathrm{i} 02.018$

Received:13 ${ }^{\text {th }}$ February, 2020; Accepted:05 ${ }^{\text {th }}$ March, 2020; Published: 18th March, 2020

\begin{abstract} 99\% in 1996, three years prior to Chavez taking office. internal situation in Venezuela.

\section{INTRODUCTION}

Venezuela is known widely for its petroleum industry, the environmental diversity of its territory, and its natural features. Home to a huge diversity of wildlife in a variety of protected habitats, Venezuela is considered to be among the 17 most megadiverse countries in the world. Unfortunately this country is known in the present time by a crisis which has been hitting it for more than two decades. It started when the collapse of oil prices took place in 1980s .At that time the economy of Venezuela contracted, the monetary sign commenced a progressive devaluation, and inflation skyrocketedto reach peak of $84 \%$ in 1989 and $99 \%$ in 1996, three years prior to Chavez taking office.
\end{abstract}

The research paper entitled (the geopolitical context of the crisis in Venezuela) Reviews the crisis Venezuela has faced when the collapse of oil prices took place in 1980s.At that time the economy of Venezuela contracted, the monetary sign commenced a progressive devaluation, and inflation skyrocketed to reach peak of $84 \%$ in 1989 and

The paper deals with Chave'z era which lasted until his death in Mar., 2013, and the economic and political problems that worsened after his vice president, Nicolas Maduro Moros, had become interim president.During this period the research paper talk about the repercussions of the interventions of the international powers on the

Key words: Hugo Chavez, oil prices, economic crisis, Maduro, United States, opposition, Guadio.

In 1999 Hugo Chavez Frias, became president after running as an independent. During his era which lasteduntil his death in Mar., 2013, Venezuela uncounted economic and political problems that worsened after his vice president, Nicolas Maduro Moros, had become interim president. In the April presidential election of the same year, Maduro was elected, but he only narrowly defeated opposition candidate Henrique CaprilesRadonski, a state governor who had lost to Chavez in 2012 by more than $10 \%$ 
Dealing with the crisis of the country, we have to take in consideration the following facts which characterize, actually the situation in Venezuela ${ }^{1}$ :

\section{1 -Maduro reclaim the presidency of the republic}

In 2015, the coalition alliance won the legislative election. Maduro, who wanted to meet the insubordination of the legislative power, established in 2017 a national assembly called " constituent ". Since that time, the representatives of the legislative and the executive sides contest to take office. However, Maduro was reelected president in May 2018.

2 -Juan Guaido also. Therefor ., a national crisis erupted in the country. Guaidó, who is one of the founders ofthe liberal right center party was elected in December 2018 a president of the national assembly for one year from the 5th of January 2019 to the $5^{\text {th }}$ of January 2020 .

When Maduro took office the $10^{\text {th }}$ of January for a second mandate ,Guaido denounced this "usurped mandate" and declared himself interim president according to article 233 of the Venezuelan constitution which confers the interim of the executive power to the president of the assembly in case of usurpation.

3 - The national and the regional reactions are contrasted. At the national level, Maduro, denounced firmly the declaration of Guaido and considered it as a coup d'état fomented by the United States. The Venezuelan high court ordered a criminal investigation against the members of the national assembly accusing them of usurping the president's Maduro prerogatives. .

3 - On the regional scale, the historical allies of Chaves, ( Cuba, Bolivia , El-Salvador, Nicaragua ) support Maduro. In contras, the group of Lima: Brasilia, Canada, Colombia, Chilly, Argentina, Costa

\footnotetext{
${ }^{1}$ Yann Figuiere. Dix points sur la crise Vénézuélienne. www, Le Grand contient ( le 4 -22019) TranslatedfromFrench.
}

Rica, Guatemala, Honduras, Panama, Equator, Pero, and Paraguay, created on 2017 to think about ending the Venezuelan crisis, showed their support to Guaido.

4 -Washington, recognize Guaido. Russia support its ally Maduro. A few minutes after his self -declaration as a president by interim, Guadio received the diplomatic recognition of the United States . Later fifty countries joined the United States. For his part, Maduro retains his traditional allies : Russia, China, Syria, Iran, and Turkey, that evoke a failed coup d'état fomented by the United States. ${ }^{2}$

5 -A crisis, first of all economic. Venezuela contains a substantial gas and petrol reserves. However a high inflationary trend has resulted in massive creation of currency during the fall in oil prices between 2014 to 2016.. In addition to the reduction of the oil exportations since November 2017 , this trend has been transformed in a biggest hyperinflation of the history of Latin America. The economic situation worsened, when the United States imposed economic sanction on the $28^{\text {th }}$ January against the Venezuelan National Company of Petrol.

The two major aspects of the Venezuelan crisis which we can underline in the five points mentioned above are economic and political. If westudy theme thoroughly, taking in account the geographic and ethnic situations in Venezuela, we can determine the major international players in the country

In the first chapter of our research paper we shall talk about the political aspect. . The second will be dealt with economic aspect, while the third chapter will focus on the geographic and ethnic situation in Venezuela before ending the research paper by the conclusion..

${ }^{2}$ Ibid. 


\section{CHAPTER ONE}

\section{THE POLITICAL ASPECT OF THE CRISIS IN VENEZUELA}

We shall start this chapter by explaining the historical evolution of the state of Venezuela. This approach can led us to understand objectively the consequences of the political crisis in the country
Christopher Columbus first sighted the coast of Venezuela in 1498. About two decades later, the Spanish began to settle in the country.

The Spanish government ruled Venezuela until the early 1800 s, when political discontent began to grow in the colony. In 1810 the revolution to gain independence from Spain began and Venezuela declared its independence a year later on July 5, 1811. This independence, however, was not decisively

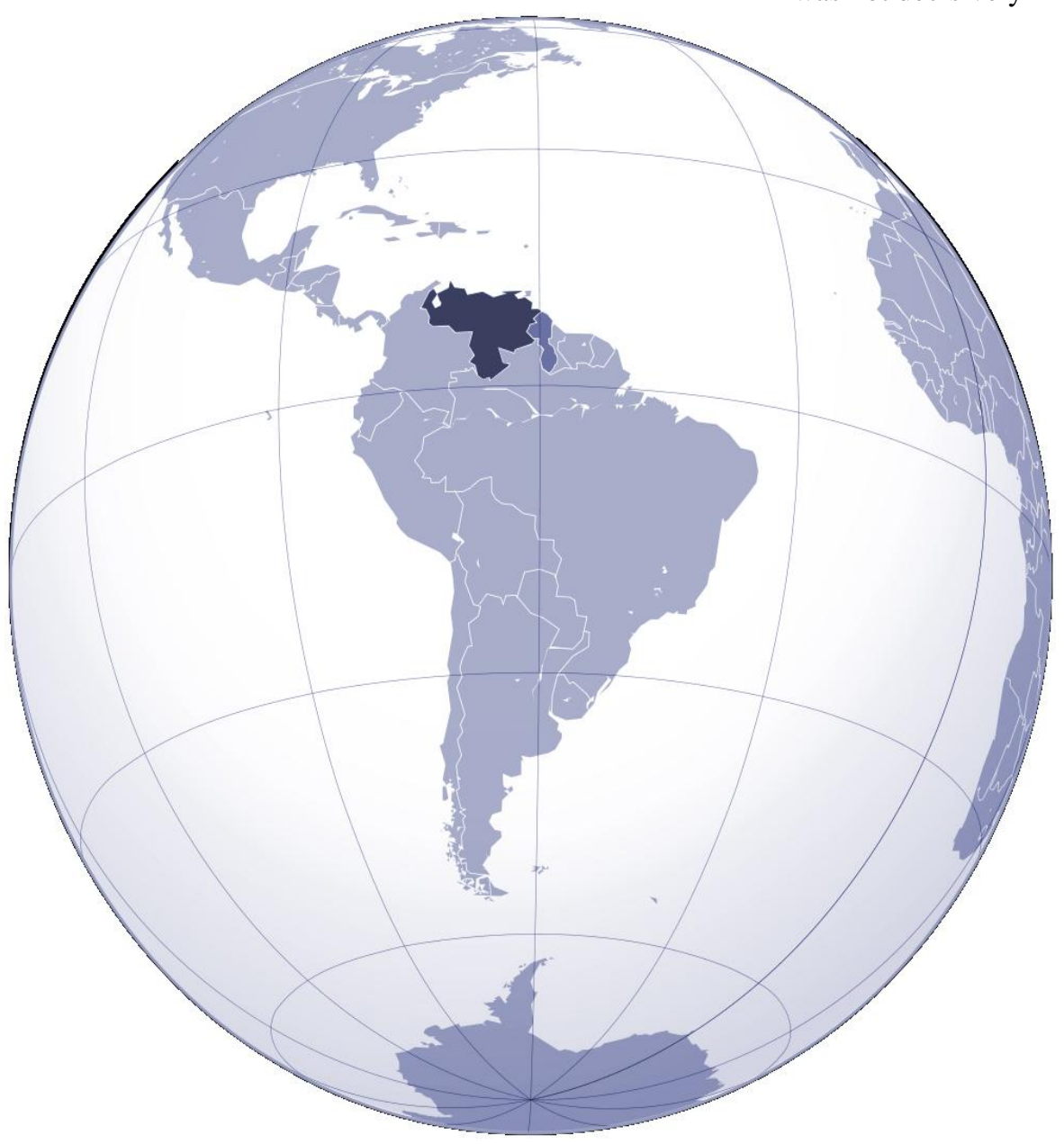

The position of Venezuela

won until Simon Bolivar's clear victory over the Spanish royalist army in $1821.2^{3}$

Venezuela's early history was marked by revolutions, counterrevolutions, and dictatorships. Juan Vicente Gómez usurped control from Castro, and Gomez remained in power until his death in 1935, with two interruptions 1931-1929;1922-1915)).

\footnotetext{
${ }^{3}$ 3.Tim Lambert. Brief history of Venezuela .www.locahistorries .org/Venezuela. Html.
} 
Although Gomez was illiterate, he had a keen sense for business. Under his rule, Venezuela developed its agricultural industry and discovered oil, making it one of the wealthiest countries in Latin America .

By 1927, oil was Venezuela's most valuable export and by 1929 Venezuela was the leading global oil exporter.

Rafael Caldera Rodriguez was elected President in 1968 and he successfully stopped guerrilla and terrorist activities. He also pursued a policy of nationalizing foreign enterprises. In December 1973 Carlos Andres Perez, leader of the center-left AcciónDemocratíca, was elected President. He continued the nationalization trend by taking over the iron and steel industry in 1975 and the oil industry in 1976.

Venezuela also experienced an economic crisis in the late 1980's that forced it to borrow money from the United States and other countries. Despite this short-term solution, the threats of violent political activity and corruption still loomed ${ }^{4}$

Hugo Chavez Frias, became president after running as an independent. He called for a halt to privatization of state assets and approved a law enabling him to rule by decree in economic matters for six months.

A referendum in Apr., 1999, called for a national constituent assembly to draft a new constitution; the assembly was elected in July and convened a month later. The assembly and Chavez engaged in a contest for power with the congress and judiciary; the assembly declared a national emergency and stripped the congress of its powers

In July, 2000, Chavez won election to the presidency under the new constitution; his coalition, the Political Pole, won 99 of the 165 seats in the assembly, short of the two-thirds majority needed to rule without constraints

His attempts to assert control over the state oil company led to strikes and demonstrations in

${ }^{4}$ 4. Ibid early 2002, and in April he was briefly ousted in a coup attempt. Latin American nations refused, however, to recognize a self-proclaimed interim government under business executive Pedro Carmona Estanga, and poorer Venezuelans mounted counter-demonstrations in his support. Chavez was restored to office and called for reconciliation; a subsequent cabinet shakeup gave his government a less ideological cast.

The ongoing political turmoil, which led to a prolonged, polarizing antigovernment strike in the vital oil industry (Dec., 2002-Feb., 2003), sent the country into recession and reduced oil exports.

In Jan., 2005, the president signed a decree establishing a national land commission that would begin the process of breaking up the country's large estates and redistributing the land.

National assembly elections in Dec., 2005, resulted in a sweep for parties supporting the president, but only a quarter of the electorate voted. Most opposition candidates withdrew from the contest before the vote in protest against what they said were biases and flaws in the electoral process, ceding complete control of the legislature to Chavez.

Chavez used Venezuela's increased oil revenues to fund social programs, to create a large military reserve and expanded militia, and to establish programs designed to reduce the effects of high energy prices on Caribbean nations ${ }^{5}$

Chavez was handily reelected in Dec., 2006, benefiting from an economic boom due to high petroleum prices and from the social programs he had instituted for the poor, but the strong win masked the continuing polarization of Venezuelan

\footnotetext{
${ }^{5}$ Julia Buxton. .Venezuela's contemporary political crisis in historical context. Bulletin of Latin America Research. Vol.24.No.3 . July 2005. Pp 328-347. Published by Wiely.
} 
society along class lines, with the poorer classes overwhelmingly favoring the president. At the same time, however, inflation was increasing, and it continued to grow throughout 2007 and 2008. Proclaiming "socialism or death" at his inauguration (Jan., 2007), Chavez moved to nationalize all energy and power companies and the country's largest telecommunications firm. He also moved to consolidate some two dozen parties supporting him into a unified socialist party, which was only partially successful, and secured the right to rule by decree for 18 months. Chavez subsequently won passage of constitutional amendments that would have ended presidential term limits, increased the length of the president's term, and enhanced the president's powers generally, but the changes failed (Dec., 2007) to win the voters' approval.

In Apr., 2008, Chavez ordered the nationalization of the cement industry and of Venezuela's largest steelmaker; additional companies and industries, perhaps most notably financial institutions, were nationalized into 2010. As his right to rule by decree expired at the end of July, 2008, Chavez signed a number of decrees that mirrored many of the constitutional amendments that voters had rejected at the end of 2007, and in Jan., 2009, he secured legislative passage of a constitutional amendment that would end term limits for all elected officials. A referendum approved the amendment in Feb., 2009.

Meanwhile, in Nov., 2008, Chavez's allies again won a majority of the posts in local and regional elections, but the opposition increased the number of posts it held and won the Caracas mayoralty. Subsequent government moves stripped significant powers from posts that opposition candidates won, further concentrating power in central government hands, and the government launched corruption investigations or other cases against a number of leading opposition figures and critics. $15^{6}$

\footnotetext{
${ }^{6}$ Who is in charge here? local democracy to communal power. (p.p 139-175) From: . The real
}

The National Assembly elections in September were won by Chavez's party, but the opposition, which did not boycott the elections, made significant gains, winning $47 \%$ of the vote and nearly $40 \%$ of the seats and denying the ruling party a constitutionally significant two-thirds majority.

In Mar., 2011, the government adopted rules authorizing the military to arm the nation's militias, a pro-government force made up of militant Chavez supporters; they had previously not been issued firearms.Chavez was again reelected in Oct., 2012, after having been treated for cancer and declaring himself fully recovered; his margin of victory was much less than in 2006. Subsequently, however, the president was again treated for cancer. This time, complications kept him in a Cuban hospital and led to the postponing of his Jan., 2013, inauguration. In Dec., 2012, Chavez's party made gains in the governors elections. Chavez died in Mar., 2013, after returning to Venezuela; Nicolas Maduro Moros, his vice president, became interim president.

Maduro received the power to rule by decree for 12 months in November, which he said was necessary to fight corruption and regulate the economy; inflation rate meanwhile increased to above 50\% in 2013 despite government price controls and remained high during 2014, when the country entered a recession. The country also suffered economically from the 2014 oil price collapse, and its economic troubles continued into 2015.

The opposition won the National Assembly elections of Dec., 2015, in a landslide, narrowly winning a two-thirds majority, but a handful of its victories were subsequently challenged in court by the ruling party. The Maduro government subsequently packed the supreme court with sympathetic judges and limited the National Assembly's powers over the central bank; the court subsequently aligned itself

Venezuela: Making Socialism in the $21^{\text {st }}$ century. lain Bruce. PlutoPress (2008) 
with Maduro in disputes with the National Assembly. ${ }^{7}$

In Jan., 2016, Maduro declared an economic emergency, allowing him to rule by edict for two months; it was extended in March and again in May, when he also declared a "state of exception," greatly increasing his powers. None of the decrees were approved by the assembly, but they were nonetheless allowed by the court.

The supreme court overturned laws passed by the National Assembly and allowed Maduro to rule without legislative approval, as the opposition meanwhile mounted several mass protests against Maduro.In Mar., 2017, the supreme court declared that the National Assembly was in contempt and that it would legislate instead.

In May, Maduro called for a constitutional assembly, to be elected by social organizations and municipal governments more supportive of the ruling party than the population; the new body was seen as a way of invalidating the freely elected National Assembly. The July election for the constitutional assembly was boycotted by the opposition, but the government claimed victory and a $40 \%$ turnout; the voting system company said turnout figures had been tampered with the new assembly dismissed the Socialist attorney general, who had become a vocal critic of Maduro and said she would investigate the July election results. She also claimed sole power to pass laws. The election of the new assembly also led to crippling new financial sanctions on the government by the United States. In the October gubernatorial elections, Maduro's party secured the vast majority of the posts despite his popularity; the opposition claimed fraud, and there was evidence of some unfairness in the voting process, but abstention by opposition voters also was a factor. ${ }^{8}$

\footnotetext{
${ }^{7}$ Run down: Venezuela's road to ruin(pp. 57-70) FromRise and fall of regional powers. HunningShur. Konard Adenauer Stifting. . (Juan 12016 )

${ }^{8}$ Ibid
}

\section{CHAPTER TWO}

\section{THE ECONOMIC SIDE OF THE CRISIS}

Since the 1920s, Venezuela has been a rentier state, offering oil as its main export. From the 1950s to the early 1980s, the Venezuelan economy experienced a steady growth that attracted many immigrants, with the nation enjoying the highest standard of living in Latin America. During the collapse of oil prices in the 1980 s, the economy contracted the monetary sign, commenced a progressive devaluation and inflation skyrocketed to reach peaks of $84 \%$ in 1989 and $99 \%$ in 1996, three years prior to Hugo Chavez taking office. $^{9}$

In spite of strained relations between the two countries, the United States has been Venezuela's most important trading partner. American exports to Venezuela have included machinery, agricultural products, medical instruments and cars. Venezuela is one of the top four suppliers of foreign oil to the United States.

About 500 American companies are represented in Venezuela. According to Central Bank of Venezuela, between 1998 and 2008 the government received around 325 billion USD through oil production and exports in general. According to the International Energy Agency (as of August 2015), the production of 2.4 million barrels per day supplied 500,000 barrels to the United States.

Since the Bolivarian Revolution half-dismantled its PDVSA oil giant corporation in 2002 by firing most of its 20,000-strong dissident professional human capital and imposed stringentcurrency controls in 2003 in an attempt to prevent capital flight, there has been a steady decline in oil production and exports and a series of stern currency devaluations, disrupting the economy.

\footnotetext{
9 Karen L. Remmer. The political impact of economic crisis in Latin America in the 1980s. The American political science review . Vol.85. No. 3 Sept.1991 pp. 777-800
} 
Further yet, price controls, expropriation of numerous farmlands and various industries, among other disputable government policies including a near-total freeze on any accessto foreign currency at reasonable "official" exchange rates, have resulted in severe shortages in Venezuela and steep price rises of all common goods, including food, water, household products, spare parts, tools and medical supplies; forcing many manufacturers to either cut production or close down, with many ultimately abandoning the country as has been the case with several technological firms and most automobile makers.

On 14 November 2017, credit rating agencies declared that Venezuela was in default with its debt payments, with Standard \& Poor's categorizing Venezuela as being in "selective default". Venezuela is ranked last among 32 countries inthe American region, and its overall score is well below the regional and world averages.

\section{CHAPTER THREE}

\section{VENEZUELA: GEOGRAPHY AND ETHNICS}

Venezuela is a country in South Americawith a population of $(29,275,000$.). Officially, it is called the Bolivarian Republic of VenezuelaIt contains $(912,050$ sq. $\mathrm{km})$.Venezuela has a coastline $1,750 \mathrm{mi}$ $(2,816 \mathrm{~km})$ long on the Caribbean Sea in the north. It is bordered on the south by Brazil, on the west and southwest by Colombia, and on the east by Guyana. Dependencies include Margarita Island, Tortuga Island, and many smaller island groups in the Caribbean. The capital and largest city is Caracas.

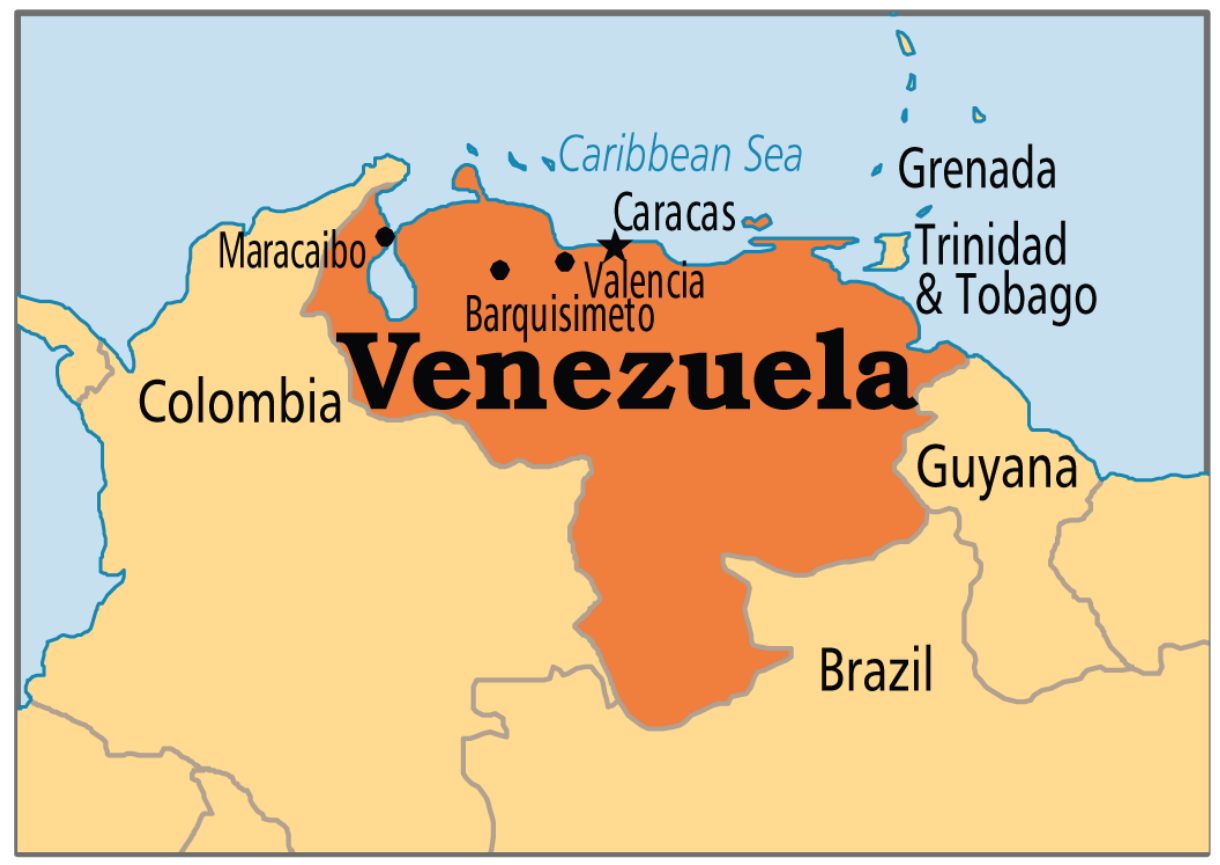

The geographical position of Venezuela

Venezuela is situated on major sea and air routes linking North and South America. It has a land area of 882,050 square kilometers, about twice the size of California, and. shaped roughlylike an inverted triangle. The country's. maritime limits borderTrinidad and Tobago, Dominica, the
Dominican Republic, Grenada, St. Kitts and Nevis, St. Vincent and the Grenadines, France, the United $\underline{\text { Kingdom, the Netherlands, and the United States }}$

Topographically speaking, Venezuela is divided into four regions: the Maracaibo lowlands in the northwest, the northern mountains extending in a 
broad east-west arc from the Colombian border along the Caribbean Sea, the wide Orinoco plains (llanos) in central Venezuela, and rank highly dissectedGuiana highlands in the southeast.mountains on three high sides and open to the Caribbean on the southeast.mountains on three high sides and open to the north. ${ }^{10}$

The climate of Venezuela varies from tropical humid to alpine, depending on the elevation, topography, and the direction and intensity of prevailing winds. Seasonal variations are marked less by temperature than by rainfall. Most of the country has a distinct rainy season; the rainy period (May through November) is commonly referred to as winter and the remainder of the year as summer.

The country falls into four horizontal temperature zones based primarily on elevation. In the tropical zone-below $800 \mathrm{~m}$-temperatures are hot, with yearly averages ranging between 26 and $28 \mathrm{C}$. The temperate zone ranges between 800 and 2,000m with averages from 12 to $25 \mathrm{C}$; many of Venezuela's cities, including the capital, lie in this region.

Colder conditions with temperatures from 9 to $11 \mathrm{C}$ are found in the cool zone between 2,000 and $3,000 \mathrm{~m}$. Pastureland and permanent snowfield with yearly averages below $8 \mathrm{C}$ cover land above $3,000 \mathrm{~m}$ in the high mountain areas known as the paramos.

Average yearly rainfall amounts in the lowlands and plains range from a semiarid $430 \mathrm{~mm}$ in the western part of the Caribbean coastal areas to around $1,000 \mathrm{~mm}$ in the Orinoco Delta. Rainfall in mountainous areas varies considerably; sheltered valleys receive little rain, but slopes exposed to the northeast trade winds experience heavy rainfall. Caracas averages $750 \mathrm{~mm}$ of precipitation annually, more than half of it falling from June to August

Lake Maracaibo occupies the central 13,500 square kilometers of the Maracaibo lowlands. The low

\footnotetext{
${ }^{10}$ Carsten Braun.\& Maximiliano BezedaThe History and Disappearance of Claciers in Venezuela... Journal of Latin American Geography. Vol 12.No.2 (2013) pp.85-124
}

swampy shores of the lake and areas beneath the lake itself hold most of Venezuela's rich petroleum deposits. The lake is shallow, with an average depth of ten meters, and separated from the Caribbean by a series of islands and sandbars. In 1955 a 7.5-meter channel was cut through the sandbars to facilitate shipping between the lake and the Caribbean.

The channel also allows salt water to mix with the yellowish fresh water of the lake, making the northern parts brackish and unsuited for drinking or irrigation.

\section{Ethnics and religious communities in Venezuela}

Christianity is the largest religion in Venezuela, with Roman Catholicism having the most adherents. The influence of the Catholic Church was introduced in its colonization by Spain. According to a 2011 poll (GIS XXI), 88 percent of the population is Christian, primarily Roman Catholic (71\%), and the remaining 17 percent Protestant, primarily Evangelicals (in Latin America Protestants are usually called Evangelicos). The Venezuelans without religion are $8 \%$ (atheist $2 \%$ and agnostic or indifferent $6 \%$ ), almost $3 \%$ of the population follow other religion (1\% of them are of Santeria) ${ }^{11}$

There are small but influential Muslim, Buddhist, and Jewish communities. The Muslim community of about 95,000 is concentrated among persons of $\underline{\text { Lebanese }}$ and Syrian descent living in Nueva Esparta State, Punto Fijo and the Caracas area; Venezuela also has a significant Druze community from the same countries (the currentvice president is Druze, showing the small group's influence). Buddhism in Venezuela is practiced by over 52,000 people. The Buddhist community is made up mainly of Chinese, Japanese, and Koreans. There are Buddhist centers in Caracas, Maracay, Merida, Puerto Ordaz, San Felipe, and Valencia. The Jewish community numbers approximately 13,000 and is mainly concentrated in

\footnotetext{
${ }^{11}$ Joel Morales. The Histories of Latin American

Church: A Handbook. Pp. (551-574).

AugsburgFortress Publishers. 2014
} 
Caracas. LDS Church (Mormons) claims 165,527 members (April 2016) mostly in and around Caracas.

\section{Mestizo}

Mestizo Venezuelans are Venezuelan people who are of a combination of European, Amerindian, and African ancestries, regardless of where they were born. They form the major part of the country's population at $51.6 \%$. The term was widely used as an ethical category in the Casta system used during the Spanish colonial period for control of their new world's colonies. Studies conducted show approximately $57 \%$ of the Mestizos possess European characteristics while $28.5 \%$ possess African characteristics, only $14.2 \%$ exhibits Amerindian characteristics.

\section{White Venezuelans}

These are Venezuelan people of predominately European descent. These people self-identify themselves as to having heritage from the European ethnic groups. The term majorly involves the physical aspect of an individual such as the light skin, shape, color of hair, and much more. They form the second largest ethnic group in the country forming $43.6 \%$ of the entire population. A study was conducted, and it showed that $61.5 \%$ of their gene pool has the European origin. ${ }^{12}$

\section{Black Venezuelans}

They are also known as Afro-Venezuelans, and these are Venezuelans of African descent, many hailing from slaves brought into South American during the Atlantic slave trade era. They represent approximately $3.5 \%$ of the total population of the country. In the 16th Century, slaves were brought to work in the copper mines, fishing, pearl mining, and small-scale farming. This trade increased in the 18th Century but the afro-Venezuelans played a major role in the struggle for independence hence the abolition

\footnotetext{
${ }^{12}$ Jonathan D. Hill. Made-from-bon. Trickster MythsMusic and History from the Amazon. (pp.147-156) . University of Illinois press. (2009).
}

of the slave trade. Their religious practices have been adapted to the Catholic religion.

\section{Indigenous Venezuelan}

These are the Native Americans who form approximately $2.5 \%$ of the country's entire population. A higher percentage of the total population of the native Venezuelan's are located in the southern Amazon rainforest, and in the Andes of the western state of Zulia. They are at least 26 indigenous groups in Venezuela such as the Baniwa people. It has been stated clearly how many people lived in the country before colonization, but the number reduced drastically after the spread of new diseases from Europe.

\section{Other Groups}

Other smaller ethnic groups found in Venezuela make up the remaining $1.2 \%$ of the country's total population. These groups are the Arab and the Middle Easterner Venezuelans, and the Asian Venezuelans. The Arab Venezuelans were settled after their immigration in the 19th and 20th Centuries, and are mainly located in the important urban areas. The Asian Venezuelans migrated from China,India,Japan, and Korea in early 1800 .

\section{Conclusion}

If we deal with the Venezuelancrisis, the following question comes to mind: what is the reason of the international interest in this crisis, and what is the foundation of this bipolarity geopolitics regarding the crisis in Venezuela? The answer is that Venezuela, thatcontains the biggest international petroleum reserve in the world,is a part of historical conflict with the United States .

The U.S.A, which, is interested in controlling the energy markets in the world, led a coalition against Venezuela consisting of the leaders of Colombia, Brazil, Argentina, and Panama. which are governed by pro- Americanpoliticians, ,in order to put pressure on Maduro to let him step down and encourage Guaido to take power through democratic elections. 
The position of the European Union was, at the beginning of the Venezuelancrisis, indecisive but later it baked the policy of the U.S.A towards Venezuela.by calling on Maduro to set a timeframe

\section{Where do countries stand on Venezuela?}

Support Maduro $\square$ Recognise Guaidó as interim president

$\square$ Calling for new elections

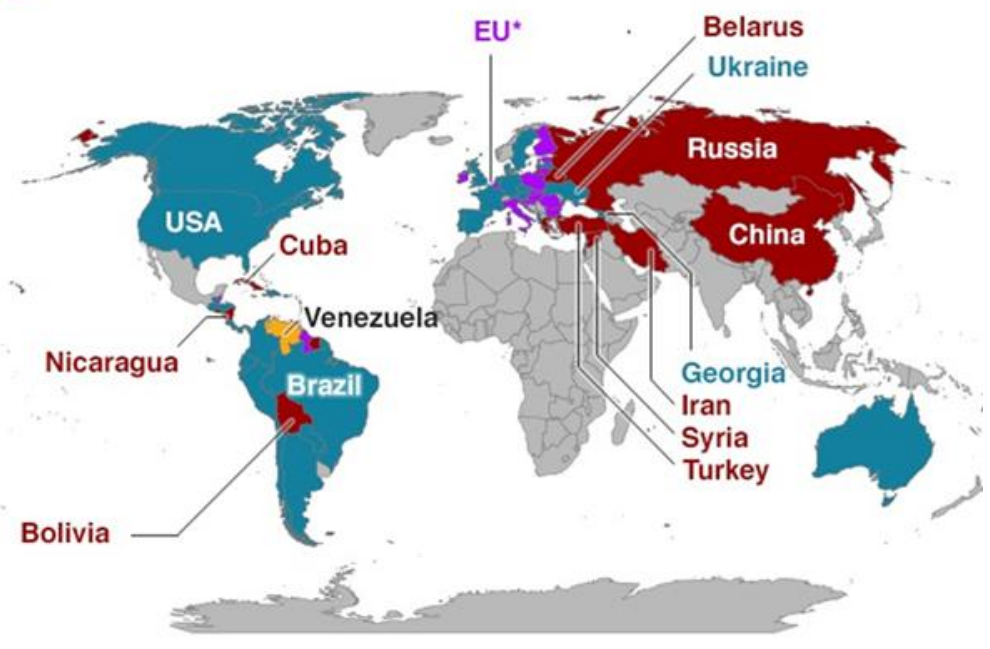

- The EU has called for new elections but some individual member countries have expressed their preferences.

Data as of 15:00 GMT 4 Feb 2019

\section{BBBC}

\section{B.B.C World Service}

The Venezuelan crisis resulted in theforming of two international camps. One of them is led by the U.S A and consisted of United Kingdom, Canada, the European Union, Australia, Ukraine and some of the LatinAmerican countries whose governments are allies of the United States. The other is involving Russia, China, Mexico, Cuba, Bolivia, Uruguay Nicaragua.Iran and Turkey.

Mr. Maduroobtained support from Russia to preventthe U.S.A from interfering in his country .Thus China and Russia took a double veto againsta project of resolution presented by the United States to the security councilaiming to support the National Assemblyled by Guido as the only party elected democratically in Venezuela. On his part, Maduro took aswift decision to transfer the Venezuelan Petroleum Company from Europe to Russia, and the for early elections. When the Venezuelan president did not met this timeframe, the E.U started to support firmly the positions of Guadio and recognized him officially as the leader of the opposition in the country . next day of the veto, the vice president of Maduro visited Mosco to coordinate the efforts with the Russian leadership to stope an American military intervention in Venezuela.

Russia does not want to protect Maduro only, but it is seeking tosecure its own economic future.associated with the prices of the oil market. China, for its part import $25 \%$ of the Venezuelan petrol and is working to dig a canal penetrating Venezuela and Nicaragua to protect its interests. Furthermore, it sent experts to rehabilitatethe electric network of Venezuela in spite of the American sanctions.China is considered as biggest lender and investor in Venezuela, and the second largest market for Venezuelan oil.India also import $22 \%$ of the Venezuelan petrol.

The internal conflict in Venezuela has a demographic dimensionwhichextenddynamically to the socio- 
economic relations of the country and then to its political circle.

The majority of the Venezuelan society is consisted of Mestizo and White Venezuelans as it is mentioned above. Poverty and ignorance spread among Mestizo but the rich intellectual elites whobelong tothe proAmerican white Venezuelans form the principle political parties and maintain good and cooperative relations withthe United States. They represent the opposition, the Federation of Chambers of Commerce, the union, the church of white Venezuelan, and the businessmen. They control economic and mass media sectors, while the government is backed by the majority of the people and the arm forces.

The United States imposed in 2017 economic sanctions on Venezuela followed by a similar measures in 2019 to force Maduro to step down of power. These sanctions have led to the collapse of the economy and the national currency It forced 3 millions of Venezuelans to immigrate to the neighboring countries, especially Colombia.

Maduro, in order to face this critical situation, offered Venezuela's gold for sale to provide food and medicine, forthe country and started printing new currency in Russia. Turkey bought 20 tons of gold while the United Arab Emirates bought 3 tons.

Maduro took another two steps : heprosecuted several opposition party leaders and arrested some of them, and gave the crisis a revolutionary ideological character to get strong support from the super powers that oppose America's international orientationthat works to create an unipolar world. Thus Venezuela joined, as we mentioned above, the camp led by Russia and became a vital part of it, and for that raison the U.S.A demanded the withdrawal of the Russian military experts from Venezuela.

If the international parts continued to interfere in the internal struggle in Venezuela, we would face situations that would be similar to those taking place in Syria

\section{BIBLIOGRAPHY}

1-Yann Figuiere. Dix points sur la crise Vénézuélienne. www, Le Grand contient ( le 4 -22019) Translatedfrom French

2-Ibid

3-3.Tim Lambert. Brief history of Venezuela .www.locahistorries .org/Venezuela. Html

4- Ibid

5- Julia Buxton. .Venezuela's contemporary political crisis in historical context. Bulletin of Latin America Research. Vol.24.No.3 . July 2005. Pp 328-347. Published by Wiely.

6- Who is in charge here? local democracy to communal power. (p.p 139-175) From: . The real Venezuela: Making Socialism in the $21^{\text {st }}$ century. Iain Bruce. PlutoPress (2008)

7- Run down: Venezuela's road to ruin (pp. 57-70) FromRise and fall of regional powers. HunningShur. Konard Adenauer Stifting. . (Juan 1 2016)

8- Ibid

9- Karen L. Remmer. The political impact of economic crisis in Latin America in the 1980s. The American political science review . Vol.85. No. 3 Sept.1991 pp. 777-800

10- Carsten Braun.\& Maximiliano BezedaThe History and Disappearance of Claciers in Venezuela.. Journal of Latin American Geography. Vol 12.No.2 (2013) pp.85-124

11- Joel Morales. The Histories of Latin American Church : A Handbook. Pp. (551-574). Augsburg Fortress Publishers. 2014

12- Jonathan D. Hill. Made-from-bon. Trickster Myths-Music and History from the Amazon. (pp.147156) . University of Illinois press. (2009). 